Original Article

\title{
EVALUATION OF ANTI-ASTHMATIC ACTIVITY OF METHANOLIC EXTRACT OF BERLERIA PRIONITIS LINN. AERIAL PARTS
}

\author{
MANEKAR SNEHAL S. ${ }^{*}$, CHARDE MANOJ S. \\ Government College of Pharmacy, SGB Amravati University, Amravati 444605, (Maharashtra) India \\ Email: snehal.manekar@gmail.com
}

Received: 11 Jul 2018, Revised and Accepted: 07 Sep 2018

\section{ABSTRACT}

Objective: The aim of the present study is to evaluate the aerial parts of a plant of Barleria prionitis Linn., for its antiasthmatic activity with the separation of active moieties.

Methods: Adult wistar albino rats were used for the anti-inflammatory study. Histamine-induced bronchospasm was conducted on isolated goat trachea.

Results: The dried and powdered aerial parts of Berleria prionitis was extracted with continuous soxhlet extraction with Petroleum ether (40-60 ${ }^{\circ}$ C), Chloroform, Ethyl acetate, Acetone, Methanol, and Hydroalcoholic solvents. Preliminary phytochemical screening of all extracts was done. Preliminary animal studies by In vitro isolated goat trachea chain preparation of all extracts were done to find out the potent extract. In this study, the methanolic extract of aerial parts of Berleria prionitis was found to be potent comparative to another extract. The results of carrageenan induced rat paw oedema model indicated the dose-dependant anti-inflammatory activity. As compared to standard drug (Indomethacin), methanolic extract showed similar activity which was found to be statistically significant $(\mathrm{P}<0.0001)$. The extent of DPPH radical scavenging was determined by calculated the IC 50 value of methanolic extract Berleria prionitis (133.5) compared with the Ascorbic acid (114.7) taken as standard. In the present study, the histamine-induced dose-dependent contraction of goat tracheal chain was significantly inhibited $(\mathrm{p}<0.001)$ by methanolic extract of aerial parts of Berleria prionitis $(200 \mu \mathrm{g} / \mathrm{ml})$. Thus the present study revealed that the methanolic extract of Berleria prionitis (MEBP) has significant antihistaminic (H1 receptor antagonist) activity.

Conclusion: In view the fact that tribal have well experienced the antiasthmatic effects of the roots of Barleria prionitis Linn. The results of our study, for the first time, show that the methanolic extract of aerial parts of Berleria prionitis Linn. possesses antioxidant, anti-inflammatory, Bronchodilator properties and therefore can be used for the antiasthmatic treatment.

Keywords: Anti-asthmatic, Antihistaminic, Anti-inflammatory, Berleria prionitis

(C) 2018 The Authors. Published by Innovare Academic Sciences Pvt Ltd. This is an open access article under the CC BY license (http://creativecommons.org/licenses/by/4.0/) DOI: http://dx.doi.org/10.22159/ijcpr.2018v10i6.30971

\section{INTRODUCTION}

Asthma was the most frequent primary diagnosis followed by AR, COPD and rhinosinusitis. Given the ongoing rapid urbanization of India, the frequency of respiratory diseases and their economic burden will continue to rise [1]. Barleria prionitis Linn. is a widely dispersed indigenous plant throughout the Indian subcontinent. In the Ayurvedic medicine of the India, it has a significant place due to its biological and pharmacological activities. The various parts of Barleria prionitis widely used to cure an array of ailments by different ethnic communities [2]. The whole plant or its parts like leaf, root, stem, bark and flower has been widely utilized for the cure of catarrhal affections, swellings, whooping cough, inflammations, toothache, glandular swellings, urinary infection, fever, gastrointestinal infections, diuretic and also in the treatment of dental infections [3].

\section{MATERIALS AND METHODS}

\section{Plant materials}

The aerial parts of plant Berleria prionitis were collected from the outfield of Amravati city, Maharashtra, India in the month of November-December. The plant materials (Ref. No-GVISH/BOT/ REPORT/10/2015) were identified and authenticated by Dr. S. N. Malode, Head, P. G. Department of Botany, Govt. Vidarbha Institute of Science and Humanities, Amravati (M. S.), India.

\section{Preparation of extract of Berleria prionitis linn}

The dried and powdered aerial parts of Berleria prionitis (500 gm) were extracted with Continuous soxhlet extraction with Petroleum ether $\left(40-60^{\circ} \mathrm{C}\right)$, Chloroform, Ethyl acetate, off the solvents and evaporated to dryness using a water bath to get the crude extract. All extracts were dried.

\section{Experimental animals}

For anti-inflammatory activity, Wistar albino rats weighing 140-160 g of either sex were used. Six animals were group housed in polypropylene cages ( $640 \times 410 \times 250 \mathrm{~mm}$ high) and kept in well cross ventilated room at the same experimental condition explained above. They were provided with standard rodent pellet diet and tap water ad libitum except the food was withdrawn $18-24 \mathrm{~h}$ before the experiment [4]. All the experimental protocols were approved by the Institutional Animal Ethics Committee (IAEC), Government College of Pharmacy, and Amravati, India (approved number-1370/ac/10/CPCSEA).

\section{Acute toxicity test (determination of LD50)}

The crude methanolic extracts and isolated compound were used for the test. Wistar rat (200-250 g) of either sex were used. This method involved an initial dose-finding the procedure, in which the animals were divided into five groups of three animals per group. Doses of 200, 600, 1000, 1500 and $2000 \mathrm{mg} / \mathrm{kg}$ were administered orally, one dose for each group. The treated animals were monitored for $24 \mathrm{~h}$ for mortality and general behavior [5].

\section{Phytochemical screening of extracts of Berleria prionitis linn}

All extracts of Berleria prionitis were subjected to phytochemical screening for tannins, glycosides, steroids, terpenoids, flavonoids, and alkaloids according to the methods of Trease and Evans.

Screening for antiasthmatic activity

A preliminary animal study by in vitro isolated goat trachea chain preparation of all extracts of Berleria prionitis Linn

Isolated adult goat tracheal tissue was obtained immediately after the slaughter of the animals. Trachea was cut into individual rings 
and tied together in series to form a chain. Trachea was suspended in bath of Kreb's solution and was continuously aerated at $37 \pm 0.5^{\circ} \mathrm{C}$. Dose-response curve (DRC) of histamine in plain Kreb's solution and in different doses of B. prionitis different extracts viz., Pet. Ether, Chloroform, Ethyl acetate, Acetone, Methanol and Hydroalcoholic in Kreb's solution were taken. Graph of percentage of maximum contractile response on ordinate and concentration of histamine on abscissa was plotted to record DRC of histamine, in the absence and in the presence of drug extracts.

\section{Isolation of phytoconstituent from the selected extract}

On the preliminary pharmacological evaluation of Antihistaminic activity, methanolic extract (ME) was found most active extract, and it was then subject to column chromatography. The concentrated methanolic extract $(20 \mathrm{~g})$ was chromatographed through a column of silica gel 60-120 mesh L. R. (diam. $4 \mathrm{cms} X$ length $45 \mathrm{cms}$ ). The column being successively eluted with increasing polarities of chloroform, chloroform: methanol and methanol. The elution was carried out chloroform: methanol in graded mixture i.e. 100, 95:05, 90:10, 85:15, $80: 20$ up to 100 methanol. From the above elution, two different fractions i.e. fraction A and B were collected. The concentration of other elutes gave only brown resinous masses which were not processed further.

\section{Antioxidant activity \\ In vitro DPPH radical scavenging activity}

The free radical scavenging activity of various extract can be measured in terms of hydrogen donating or radical scavenging ability using the stable radical DPPH. Prepare $0.1 \mathrm{mmol}$ solution of DPPH in Methanol and add $1.0 \mathrm{ml}$ of this solution to $3.0 \mathrm{ml}$ of methanolic Berleria prionitis extract and isolated fraction (F1BP) in different concentrations $(25-800 \mu \mathrm{g} / \mathrm{ml})$. Thirty minutes later, measure the absorbance at $517 \mathrm{~nm}$. Lower absorbance of the reaction mixture indicates higher free radical scavenging activity.

\section{Preparation of extract dilution}

$50 \mathrm{mg}$ of $B$. prionitis methanolic extract was weighed separately and dissolved in $100 \mathrm{ml}$ of methanol to get $500 \mu \mathrm{g} / \mathrm{ml}$ stock solutions. Lower concentrations $(25,50,100,150,200,250 \mu \mathrm{g} / \mathrm{ml})$ were prepared by diluting serially with methanol.

\section{Preparation of standard dilution}

Ascorbic acid weighed (50 mg) separately and dissolved in $100 \mathrm{ml}$ of methanol to get $500 \mu \mathrm{g} / \mathrm{ml}$ stock solutions. Lower concentrations $(50,100,150,200,250 \mu \mathrm{g} / \mathrm{ml})$ were prepared by diluting serially with methanol.

\section{Anti-inflammatory activity \\ Carageenan induced paw edema in rat}

Carrageenan-induced hind paw edema model can be used for determination of anti-inflammatory activity. $60 \mathrm{~min}$ after the oral administration of methanolic B. prionitis extracts $(200 \mathrm{mg}$ and $400 \mathrm{mg} / \mathrm{kg}$ ) and fraction $1 \mathrm{BP}$ (F1BP), allow each rat to inject with the freshly prepared suspension of carrageenan 0.5 $\mathrm{mg} / 25 \mathrm{mcl}$ ) in physiological saline into subplantar tissue of the right hind paw. As the control, Inject 25 micro liter saline solutions into that of the left hind paw. Measure the Paw edema in the intervals of $0,1,2,3,4,5$ and $6 \mathrm{hr}$. after induction of inflammation. Measure the difference in footpad thickness. Compare the mean values of treated groups with those of a control group and analyzed by using statistical methods. Use Indomethacin $(10 \mathrm{mg} / \mathrm{kg})$ as the reference drug.

Table 1: Experimental design: carageenan induced paw edema in rat

\begin{tabular}{lll}
\hline Group & Treatment & Dose \\
\hline I & Control (Normal saline) & $2 \mathrm{ml} / \mathrm{Kg} \mathrm{b} . \mathrm{wt}$ \\
II & Standard Indomethacin & $10 \mathrm{mg} / \mathrm{Kg} \mathrm{b} . \mathrm{wt}$ \\
III & Methanolic extract of Berleria prionitis (Lower) & $200 \mathrm{mg} / \mathrm{Kg} \mathrm{b} . \mathrm{wt}$ \\
IV & Methanolic extract of Berleria prionitis (Higher) & $400 \mathrm{mg} / \mathrm{Kg} \mathrm{b} . \mathrm{wt}$ \\
VII & Fraction 1 Berleria prionitis (Lower) (F1BP) & $200 \mu \mathrm{mg} / \mathrm{ml}$ \\
VIII & Fraction 1 Berleria prionitis (Higher) & $400 \mu \mathrm{mg} / \mathrm{ml}$ \\
\hline
\end{tabular}

\section{Bronchodilator activity}

Inhibition of histamine-induced contraction in isolated goat tracheal chain preparation. (In vitro model)

Isolated adult goat tracheal tissue was obtained immediately after slaughter of the animals. Trachea was cut into individual rings and tied together in series to form a chain. Trachea was suspended in bath of Kreb's solution and was continuously aerated at $37 \pm 0.5{ }^{\circ} \mathrm{C}$. Dose-response curve (DRC) of histamine in plain Kreb's solution and in different doses of methanolic extract of $B$. prionitis and isolated fraction (F1BP) in Kreb's solution were taken. Graph of percentage of maximum contractile response on ordinate and concentration of histamine on abscissa was plotted to record DRC of histamine, in absence and in the presence of drug extracts.

\section{Statistical analysis}

The statistical analysis was performed by using one-way analysis of variance (ANOVA) followed by Dunnett's test for individual comparison of groups with the control. The $\mathrm{p}$ values less than 0.001 were considered as significance.

\section{RESULTS AND DISCUSSION}

A preliminary animal study by In vitro isolated goat trachea chain preparation of all extracts of Berleria prionitis

It was observed that methanolic extract of Berleria prionitis (MEBP) inhibits contraction produced by histamine in these tissue preparations as compared to the pet ether, chloroform, ethyl acetate, acetone and hydroalcoholic extract of BP. Histamine $(30 \mu \mathrm{g} / \mathrm{ml})$ was taken in different dose level and DRC was plotted. Study revealed that Methanolic extract exhibits significant $(\mathrm{p}<0.001)$ percentage decreased contraction at concentration $200 \mu \mathrm{g} / \mathrm{ml}$ in goat tracheal chain preparation.

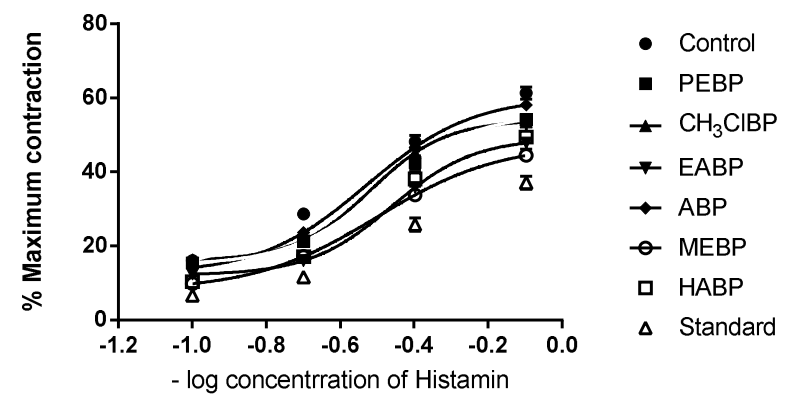

Graph 1: Effect of all extracts of aerial parts of Berleria prionitis on histamine induced bronchospasm, values are expressed as mean \pm SEM ${ }^{* * *} \mathbf{p}<0.0001 ; \mathbf{n s}=$ nonsignificant, compared with standard Group (one-way ANOVA followed by Dunnett's Multiple Comparisons test)

Acute toxicity study of aerial parts methanolic extract of Berleria prionitis linn

The methanolic extract of B. prionitis (MEBP) and isolated fraction F1BP were administered to a group of experimental animals at 
doses that is 100200 and $400 \mathrm{mg} / \mathrm{kg}$ was selected for this study. The acute oral toxicity study was carried out as per the OECD guidelines found that both methanolic extract and isolated fraction were safe at limit dose of $2000 \mathrm{mg} / \mathrm{kg}$ with no mortality in studied animals. $1 / 10$ th of these doses i.e. $200 \mathrm{mg} / \mathrm{kg}$ and doubling of that dose that is $400 \mathrm{mg} / \mathrm{kg}$ and half of $1 / 10$ dose that is $100 \mathrm{mg} / \mathrm{kg}$ were used in the subsequent study respectively.

\section{Phytochemical screening of extracts of Berleria prionitis linn}

In phytochemical screening methanolic BP extract contain Alkaloids, Phenolic and Tannins, Saponin, Glycoside, Flavonoid, Phytosterol, Protein, Carbohydrate.

\section{Isolated compound from aerial parts of Berleria Prionitis Linn}

TLC profiling of isolated compound (F1BP) from aerial parts of Berleria prionitis linn

Fraction A was eluted from Choloroform: methanol (80:20), resulted as a single compound, which was confirmed by TLC
( $\left.\mathrm{CHCl}_{3}: \mathrm{MeOH} ; 7: 3\right)$. The product was designated as F1BP. Visualization was carried out by spraying Vanillin-Sulphuric acid reagent (VS) and detection was carried out visually in visible light and under UV light.

Dipping the plate in iodine chamber also shows color spot. Rf value of F1BP was found to be 0.34 .

\section{Antioxidant activity}

\section{In vitro DPPH radical scavenging activity}

The result of DPPH scavenging activity assay in this study indicates the methanolic extract was potentially active. The scavenging activity of methanolic extract compared with the standard drug ascorbic acid suggest that the plant is also a potent scavenger of free radicals. The antioxidant activity on the basis of their IC50 values was methanolic BP extract (IC50 $133.5 \mu \mathrm{g} / \mathrm{ml}$ ) and isolated compound FIBP $(191.6 \mu \mathrm{g} / \mathrm{ml})$. Results were compared with ascorbic acid (IC50 $114.7 \mu \mathrm{g} / \mathrm{ml}$ ).

Table 2: Percent inhibition of DPPH absorbance at different concentrations of standard (ascorbic acid)

\begin{tabular}{llll}
\hline Concentraction $(\boldsymbol{\mu g} / \mathbf{m l})$ & \% Inhibition & \\
\cline { 2 - 4 } & MEBP & F1BP & STANDARD \\
\hline 25 & 07.92 & 5.48 & 9.75 \\
50 & 12.19 & 8.53 & 19.51 \\
100 & 25 & 15.24 & 31.70 \\
200 & 34.14 & 41.31 & 40.24 \\
400 & 38.41 & 51.82 & 65.41 \\
800 & 56.09 & 50.60 & 45.73 \\
\hline
\end{tabular}

Absorbance of control: 0.164 , values are expressed as mean \pm SEM, ${ }^{* *} \mathrm{p}<0.01,{ }^{* * *} \mathrm{p}<0.0001$; ns =non-significant, compared with Standard (one-way ANOVA followed by Dunnett's Multiple Comparisons test).

\section{DPPH ASSAY BP}

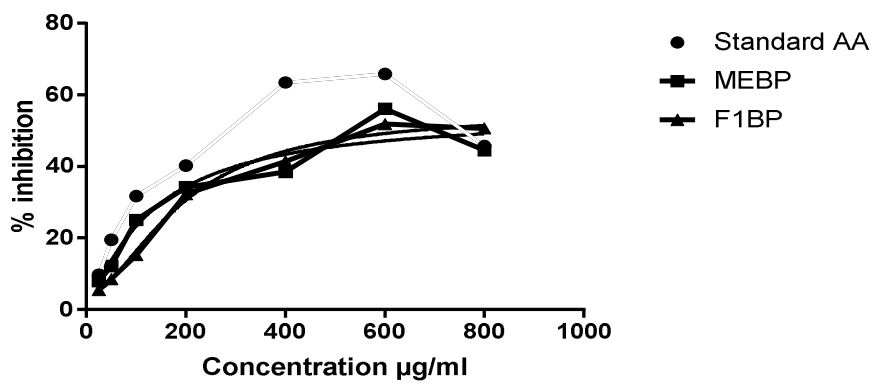

Graph 2: Effect of $B$. Prionitis methanolic extract and an isolated fraction on DPPH antioxidant assay, values are expressed as mean \pm SEM, ${ }^{* *} \mathbf{p}<0.01, * * * \mathbf{p}<0.0001 ; \mathbf{n s}=$ non-significant, compared with Standard (one-way ANOVA followed by Dunnett's Multiple Comparisons test)

Table 3: Comparison of $\mathrm{IC}_{50}$ of extracts and isolated fraction from $B$. prionitis

\begin{tabular}{ll}
\hline B. prionitis extract & $\mathbf{I C} \mathbf{5 0} \mathbf{\mu g} / \mathbf{m l}$ \\
\hline Standard Ascorbic acid & 114.7 \\
MEBP & 133.5 \\
F1BP & 191.6 \\
\hline
\end{tabular}

Mean values $(\mathrm{P}<0.001)$ according to Duncan's Multiple Range Test.

Table 4: Anti-inflammatory activity of methanolic extract of $B$. prionitis L. by carrageen induced rat paw edema

\begin{tabular}{|c|c|c|c|c|c|c|c|}
\hline \multirow[t]{2}{*}{ Group } & \multirow[t]{2}{*}{ Dose mg/Kg } & \multicolumn{6}{|c|}{ \% Inhibition } \\
\hline & & $1 \mathrm{~h}$ & $2 \mathrm{~h}$ & $3 \mathrm{~h}$ & $4 \mathrm{~h}$ & $5 \mathrm{~h}$ & $6 \mathrm{~h}$ \\
\hline Indomethacin & 10 & 48.64 & 57.35 & 63.51 & 61.84 & 58.57 & 56.52 \\
\hline \multirow[t]{2}{*}{ MEBP } & 200 & 18.91 & 29.41 & 40.54 & 48.68 & 45.71 & 44.92 \\
\hline & 400 & 43.24 & 26.47 & 51.35 & 59.21 & 57.63 & 55.07 \\
\hline \multirow[t]{2}{*}{ F1BP } & 200 & 18.91 & 20.58 & 10.81 & 17.10 & 10 & 10.14 \\
\hline & 400 & 24.32 & 27.94 & 21.62 & 28.94 & 28.57 & 27.53 \\
\hline
\end{tabular}




\section{Anti-inflammatory activity}

\section{Carageenan induced paw edema}

In the caragennan induced rat paw edema test (table-I, fig-I andII), methanolic extract of BP (MEBP) and isolated compound (F1BP) (200 $\mathrm{mg} / \mathrm{kg}$ ) showed significant $\left({ }^{* * *} \mathrm{P}<0.0001\right.$ ), with $48.68 \%$ and $17.10 \%$ inhibition of edema respectively at the end of $4 \mathrm{~h}$. At a dose of 400 $\mathrm{mg} / \mathrm{kg}$ methanolic extract of BP (MEBP) and isolated compound
(F1BP) showed significant $\left({ }^{* * *} \mathrm{P}<0.0001\right)$ with $\%$ and 59.21 and $28.94 \%$ inhibition of edema respectively at the end of $4 \mathrm{~h}$ as compared with reference drug indomethacin $\left({ }^{* * *} \mathrm{P}<0.0001\right)$ with $61.84 \%$ inhibition of edema. The caragennan induced rat paw edema is a biphasic process $[19,20]$. From the result methanolic extract of BP (MEBP) and isolated compound (F1BP) $400 \mathrm{mg} / \mathrm{kg}$ showed more percentage of inhibition against caragennan induced paw edema which is comparable with reference standard Indomethacin.

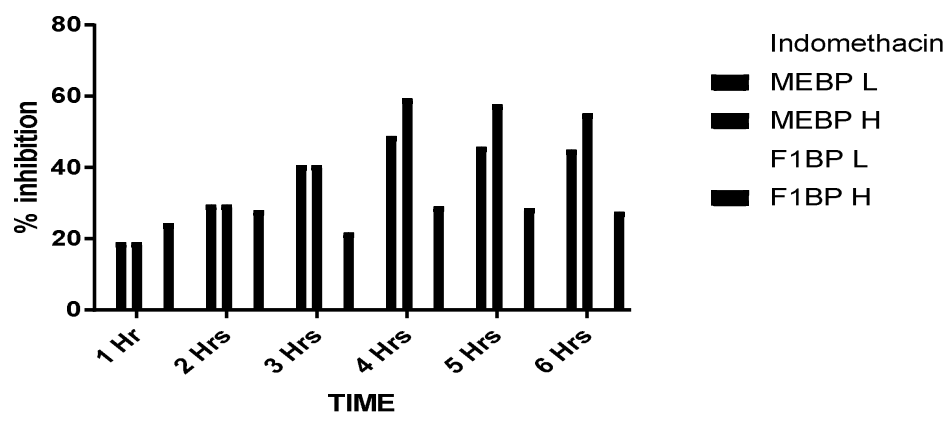

Graph 3: Effect of $B$. Prionitis methanolic extract and isolated fraction on carrageenan-induced rat paw oedema, values are expressed as mean \pm SEM $(\mathrm{n}=6),{ }^{* *} \mathbf{p}<0.01, * * * \mathbf{p}<0.0001 ; \mathrm{ns}=$ non significant, compared with disease control group (one-way ANOVA followed by Dunnett's multiple comparisons test)

\section{Bronchodilator activity}

Inhibition of histamine-induced contraction in isolated goat tracheal chain preparation. (In vitro model)

It was observed that methanolic extract of Berleria prionitis Linn. Inhibits dose-dependent contraction produced by histamine (30 $\mu \mathrm{g} / \mathrm{ml}$ ) as indicated in the graph of maximum percentage of contractile response $\mathrm{v} / \mathrm{s}$ negative log molar concentration of histamine. Study revealed that methanolic extract of Berleria prionitis exhibits significant $(\mathrm{p}<0.001)$ percentage decreased contraction at concentration $200 \mu \mathrm{g} / \mathrm{ml}$ in goat tracheal chain preparation

Table 5: Effect of Berleria prionitis methanolic extract on histamine-induced contraction on isolated goat tracheal chain preparation

\begin{tabular}{|c|c|c|c|c|}
\hline \multirow[t]{2}{*}{ Dose of histamine $(30 \mu \mathrm{g} / \mathrm{ml})$} & \multicolumn{4}{|c|}{ \% maximum contraction (mean \pm SEM) } \\
\hline & Control group & MEBP & F1BP & Standard \\
\hline 0.1 & $17.8 \pm 0.90$ & $10.78 \pm 1.31$ & $12.46 \pm 0.61$ & $9.21 \pm 0.52$ \\
\hline 0.2 & $41.03 \pm 1.69$ & $26.63 \pm 1.30$ & $24.16 \pm 2.19$ & $21.19 \pm 0.74$ \\
\hline 0.4 & $62.51 \pm 1.28$ & $38.49 \pm 1.24$ & $46.65 \pm 1.41$ & $34.87 \pm 0.54$ \\
\hline 0.8 & $73.45 \pm 0.89$ & $46.65 \pm 1.40$ & $58.09 \pm 1.04$ & $42.45 \pm 1.14$ \\
\hline
\end{tabular}

Each value represents the mean \pm SEM; ns Not significant, ${ }^{*} P<0.05$, significant; $* * * P<0.0001$ vs. control (histamine), one-way ANOVA followed by Dunnett's $t$-test.

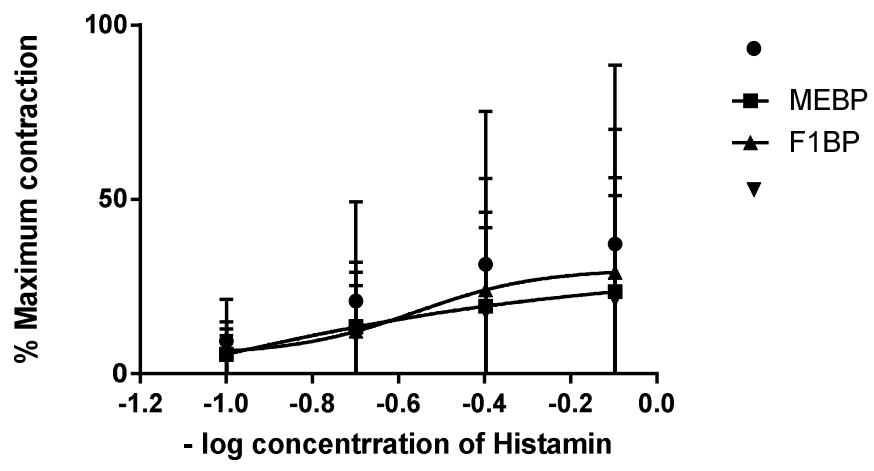

Graph 4: Bronchodilator activity Of B. prionitis extract and isolated fraction (Inhibition of tracheal tissue contraction, values are expressed as mean $\pm \mathrm{SEM}^{* *} \mathrm{P}>\mathbf{0 . 0 0 1}$ significant compared to control group by one way ANOVA followed by Dunnett's multiple comparison test

\section{CONCLUSION}

The results of the investigation revealed that methanolic extracts of the $B$. prionitis showed significant DPPH radical activity which was calculated in terms of IC50. There was no major difference in the
DPPH radical scavenging activity of methanolic extract and isolated compound.

From the present study, it is concluded that methanolic extract of $B$. prionitis showed maximum percentage inhibition (59.21\%) of rat 
paw edema at a dose of $400 \mathrm{mg} / \mathrm{kg}$. Anti-inflammatory activity was found to be dose-dependent.

Histamine contracts the tracheobronchial muscle of guinea pig, goat, horse, dog and man. Goat tracheal chain is easier to handle and to prepare; it is also much more sensitive than a guinea pig tracheal chain. The goat tracheal muscle has $\mathrm{H} 1, \mathrm{M} 3$, and B2 receptors. The stimulation of $\mathrm{H} 1$ receptors caused contraction of the bronchial smooth muscle. In the present study, there is a right side shift of Dose Response Curve (DRC) of histamine in the presence of a methanolic extract of Berleria prionitis indicating antiasthmatic action.

\section{ACKNOWLEDGMENT}

We are grateful to the Government College of Pharmacy, Amravati, Maharashtra, India for providing the facilities during the course of this study. Special thanks to Dr. S. N. Malode, Head, P. G. Department of Botany, Govt. Vidarbha Institute of Science and Humanities, Amravati (M. S.), India. for identification and authentication of the plant.

\section{AUTHORS CONTRIBUTIONS}

All the author have contributed equally

\section{CONFLICT OF INTERESTS}

\section{Declared none}

\section{REFERENCES}

1. Aloke Gopal Ghoshal, GD Ravindran, Paras Gangwal, Girish Rajadhyaksha, Sang-Heon Cho. The burden of segregated respiratory disease in India and the quality of care in these patients: results from the Asia-Pacific burden of respiratory diseases study. Lung India 2016;33:611-9.

2. Ajeet Singh, Navneet. A review: traditional, ethnomedicinal utilization, pharmacological properties, and phytochemistry of Barleria prionitis Linn. Int J Pharm Sci Rev Res 2017;44:19-26.

3. Kamini Singh, Deepika Sharma, Gupta Rs. A comprehensive review on Barleria Prionitis (L.). Asian J Pharm Clin Res 2017;10:22-9.

4. Sachin Parmar, Amit Gangwal, Navin Sheth. Evaluation of the antiasthmatic activity of a polyherbal formulation containing four plant extracts. J Curr Pharma Res 2010;2:40-4.
5. J Shetty Akhila, Shyamjith, Deepa, MC Alwar. Acute toxicity studies and determination of median lethal dose. Curr Sci 2007;93:7.

6. Alam MM, Anis M. The medicinal plants of gunung leuser national park, Indonesia. J Ethnopharmacol 1987;19:85-8.

7. Alzweiri M, Sarhan AA, Mansi K, Hudaib M, Aburjai T. Ethnopharmacological survey of medicinal herbs in Jordan, the Northern Badia region. J Ethnopharmacol 2011;137:27-35.

8. Aneja KR, R Joshi, C Sharma. The potency of berleria prionitis L. bark extracts against oral diseases causing strains of bacteria and fungi of clinical origin. New York Sci J 2010;3:5-12.

9. Aqil F, Ahmad I, Mehmood Z. Antioxidant and free radical scavenging properties of twelve traditionally used Indian medicinal plants. Turkish J Biol 2006;30:177-83.

10. Banerjee D, Maji A, Banerji P. Barleria prionitis linn: a review of its traditional uses, phytochemistry, pharmacology and toxicity. Res J Phytochem 2012;6:31-41.

11. Chen JL, Blanc P, Stoddart CA, Bogan M, Rozhon EJ, Parkinson $\mathrm{N}$, et al. New iridoids from the medicinal plant Barleria prionitis with potent activity against the respiratory syncytial virus. J Nat Prod 1998;61:1295-7.

12. Kapoor A, Shukla S, Kaur R, Kumar R, Lehra KS, Kapoor S. Preliminary phytochemical screening and antioxidant activity of whole plant of Barleria prionitis Linn. Int J Adv Pharm Biol Chem 2014;3:410-9.

13. Khadse CD, Kakde RB. Anti-inflammatory activity of aqueous extract fractions of Barleria prionitis L, roots. Asian J Plant Sci Res 2011;1:63-8.

14. Maji AK, Bhadra S, Mahapatra S, Banerji P, Banerjee D. Mast cell stabilization and membrane protection activity of Barleria prionitis L. Pharmacogn J 2011;3 Suppl 24:67-71.

15. Sharma P, Sharma GN, Shrivastava B, Jadhav HR. Evaluation of antioxidant potential of Barleria prionitis Leaf and stem. Am J Phytomed Clin Ther 2014;2:1177-86.

16. Singh B, Bani S, Gupta DK, Chandan BK, Kaul A. Antiinflammatory activity of TAF an active fraction from the plant Barleria prionitis Linn. J Ethnopharmacol 2003;85:187-93.

17. Trease, William C Evans. Textbook of Pharmacognosy. 16 edition. Elesvier publication; 2009. 